\title{
Supporting the educational career of children from divorced families: parents' experiences and the role of the school
}

\author{
H. Colpin ${ }^{\star}$, L. Vandemeulebroecke and P. Ghesquière \\ University of Leuven (K.U. Leuven), Belgium
}

This study investigated experiences and needs concerning (supporting) children's school career among parents in divorced lone-parent and stepfamilies. Forty custodial parents from a variety of divorced family situations responded to an in-depth interview. The interview data were analysed using qualitative methods. The results show a variety of experiences and needs for support among different families. In general, a respectful attitude from the school, a flexible way of handling the diversity of family situations and teachers' commitment to the psychosocial well-being of the child are essential tools in supporting children and promoting parental involvement and support. It is suggested that these measures be optimally realized within the context of an integrated school policy concerning the relationship with the family.

\section{Introduction}

A growing number of children are living in non-traditional families, mainly as a consequence of rising divorce rates. Between $10 \%$ and $15 \%$ of families with children in Western European countries are lone-parent families; for the United Kingdom and Sweden, values between $20 \%$ and $25 \%$ are reported. The large majority are lonemother families; in the United Kingdom they account for 19\% of all families with dependent children, about 2 million children are living in lone-mother households (Duncan \& Edwards, 1997, 1999; Eurostat, 1998; Haskey, 1998). Data from the United Kingdom demonstrate that one in eight children, at some time during childhood and adolescence, lives in a household with a biological parent who has formed a new partnership through cohabitation or remarriage (Haskey, 1994).

This reality presents our society with new questions and challenges, including regarding the education system. Research has shown that the family situation can

${ }^{\star}$ Corresponding author. Centre for School Psychology, Tiensestraat 102, 3000 Leuven, Belgium. Email: hilde.colpin@psy.kuleuven.ac.be 
influence the academic and socio-emotional adjustment of children at school. Numerous studies have found limited but significant and persistent differences between children from divorced families and children from traditional families: the former present more externalizing and internalizing problem behaviour, have more academic problems and move on to higher education less frequently (for reviews, see David, 1993; Hetherington et al., 1998; Morgan, 1998).

Research into risk and protective factors from an ecological point of view has revealed that proximal environmental experiences can mediate the negative influence of structural family factors (Felner et al., 1995; Hetherington et al., 1998; Golombok, 2000). Both school and home support play a protective role for the children's performance and well-being at school. In a study by Hetherington (1993), four different school types were distinguished, referring to different parenting styles: authoritative, authoritarian, permissive and chaotic/neglecting schools. All factors referring to an authoritative style were significantly associated with greater achievement and social competence and less problem behaviour among boys and girls from divorced and remarried families. An interaction effect between authoritative parenting and authoritative schooling was found. Furthermore, the school adjustment of children from divorced families is positively influenced by supportive and authoritative parenting practices in general, and parental involvement in their school education in particular (e.g. supervising and monitoring school activities and homework, attending meetings and contacts with the teacher, participating and assisting in school events) (Downey, 1994; Pong, 1997).

It has been shown that divorced parents, as a group, are less involved in their children's school career than parents from intact two-parent families. The differences remain significant when the parents' educational level and income are controlled for (Downey, 1994; Entwisle \& Alexander, 1996; Pong, 1997). These studies show that lone parents often have less time for general supervision and daily monitoring of their children's homework. Parents and children also communicate less about school matters than parents and children in traditional two-parent families. The presence of a second adult in stepfamilies does not necessarily result in increased parental involvement or support. A study by Bosman and Louwes (1989) revealed that most children have negative feelings about their mother's new relationship. These negative feelings contribute significantly to the differences in the school career of children from divorced mother families and those from intact two-parent families.

Griffith and Smith (1991) argue that parental involvement schemes implicitly depend on the existence of the nuclear, two-parent family, with breadwinner father and stay-at-home mother. This family model releases the mother for household and school work, and portrays other ways of living and different family forms as problematic. Expectations of parental participation in schooling have escalated in recent decades, precisely at the same time that changes in family structure have reduced familial resources for participating in schooling. It has been argued that these changes in family life have not been taken into account sufficiently by teachers, school systems and policy-makers, creating a situation that in effect reproduces social and educational inequalities in a more complex form. It is important that future research 
agendas attempt to consider these issues and their implications for policy (Lareau, 1989; Epstein, 1990; David, 1993).

The present study — subsidized by the Flemish Ministry of Education - investigated how parents and the school can support the school career of children from divorced families; in particular, how the school can help parents in divorced families to give optimum support to their child's school career. This question is studied from the parents' point of view, so as to take account of their perceptions and needs in policymaking. There has been very little research from the perspectives of parents on the impact and effects of family changes on public policies and school practices (David, 1993). In the present study we aim to help bridge this gap. Moreover, this approach is in line with current ethnographic research on the psychological and social consequences of divorce and diverse family forms (Smart \& Neale, 1999; Ribbens McCarthy et al., 2003).

Two groups of questions were studied:

1. Concerning the parents' perception of their own support for the child's educational career: Do parents experience difficulties in supporting the child's schooling? Do they feel their support and involvement are different from that of parents in traditional families?

2. Concerning the parents' perception of the support offered by the school: Do they feel the support offered by the school is different from the support given to children from traditional families? How could the support offered by the school be optimized?

\section{Methods}

Qualitative methods were used to obtain an in-depth overview of the experiences and needs of divorced parents concerning (support for) their child's school career (cf. Miles \& Huberman, 1994; Denzin \& Lincoln, 1998).

\section{Subjects}

The intended sample consisted of 40 divorced, custodial parents ${ }^{1}$. Taking into account the qualitative character of the research design, we aimed to introduce variation in the characteristics of divorced families in the research group as much as possible, in order to elicit broad-based understandings of the perceived needs for support among different family situations. In this respect, it was appropriate to use the technique of 'theoretical purpose sampling' (Guba, 1981), 'that is, sampling that is not intended to be representative or typical [...] but to maximize the range of information uncovered. The nature of the sampling process is governed by emergent insights about what is important and relevant' (Guba, 1981, p. 86). With this technique, we aimed to maximize variation in our data-set with regard to the essential features of the study group (see later).

The sample was recruited with the assistance of 15 primary schools in Flanders 
(Belgium). The selection of primary schools was based on six criteria: location in Flanders (distribution over five provinces), educational networks (distribution over three different networks, a specific characteristic of the school system in Flanders), level of urbanization, number and socio-economic status of the children in the schools and the social and pedagogical school climate.

All pupils at these 15 schools (about 3100) received a letter for their parents explaining the purpose of the study and asking the parents 'whose children were not living with both biological parents, married or living together' to participate. Fifty-six divorced parents ( 40 from lone-parent families and 16 from stepfamilies) returned the reply card enclosed with the letter. Therefore, about $2 \%$ of the children's parents responded; this is an underestimation of the real proportion of respondent families, since some parents had more than one child at the school. Secondary analyses in the Panel Study on Belgian Households revealed that about 9\% of 7-year-old to 12-yearold children live in a lone-parent or stepfamily (some of which are not the result of divorce, but of the death of a parent or the deliberate choice of single motherhood) (Child and Family, 2001). We estimate that more than $22 \%$ of divorced families responded to the research letter.

Subsequently, all 56 parents were contacted for an interview by telephone in order to explain the study in more detail and to collect some information about their family situation. Following this interview, 40 families were selected using the technique of theoretical sampling (see earlier).We aimed for maximum variation of the following characteristics: family type (lone parent or stepfamily), custodial arrangement, parents' and children's sex, school and grade of the child and the presence of step and/ or half-siblings in the families. The 16 families that were not selected were very similar to one or more of the selected families in terms of these characteristics.

Within the sample of 40 divorced parents, 26 belonged to a lone-parent family and 14 to a stepfamily (among the latter parents, five had remarried and nine were cohabiting with a new partner). In 36 families, the parent had divorced once, and four mothers had divorced twice. The group of divorced families included five parents with a coparenting arrangement. Where there was no shared custody arrangement, most of the cases were represented by lone-mother families $(n=31)$; all the families with a lone father $(n=4)$ were included in the sample. The families were equally divided among the three educational networks and the six years of primary school. The educational level of the parents was comparable with that of a representative sample of lone parents in another study (Speltinckx \& Jacobs, 1996). The rate of employment among the lone mothers in our group - $75 \%$ of these mothers had a job-was slightly higher than was found in another study concerning lone mothers in Belgium (about 69\%) (Ditch et al., 1998). Both sexes of children were equally represented in the sample.

\section{Instrument}

In order to collect the data, a semi-structured in-depth interview was developed. First, we developed more specific indicators for the research questions. Then these indicators were translated into more operational open questions. Parental support was 
described as every possible kind of involvement with the child's school career. Concerning support by the school, we asked questions about child guidance and the parent-school relationship in general, and how the school copes with issues related to the specific family situation in particular. We chose broad and general definitions of support, so as not to exclude any type of support that might be relevant for our subjects.

The interview took place at home and lasted one to two hours. In order to account for the singularity of each family and the diversity of experiences and needs, the interview questions could be adapted to the specific family history because they were linked to the particular family arrangement of the respondent.

\section{Data analysis}

The interviews were recorded and typed in their entirety. Based on an initial reading of the complete interviews, a coding grid was developed in an inductive way. Broad, general categories were developed in order to avoid losing any interesting material.

With regard to the interpretation of the interviews with the parents, we developed a coding system with six categories. The first two categories refer to the first research question (concerning the perceptions of parental support for school education): (1) the parents' support of their children's educational career; and (2) a comparison between this parental support and that of parents in traditional families.

The next four categories are associated with the second research question (concerning the perceptions of the support offered by the school): (3) the relationship between the family and the school; (4) the school support received and desirable; (5) the influence of family type on the school's attitudes and support for the child and the parents; and (6) the (parenting) support received from other institutions.

Subsequently, the interviews were analysed using these categories, with the assistance of the QSR NUD`IST 4 software program (Geenen, 1999). For each interview, the categories were matched to the statements of the respondents. Finally, the statements were regrouped per category and a global analysis of the content of each category was carried out. Possible links between the themes of the different categories and other variables (such as the family type and the parent's sex) were also brought into perspective.

In order to enhance the validity of our findings, we organized a 'member check' (Guba, 1981) in the form of a roundtable discussion with seven parents who participated in the interviews. We presented them with the preliminary results and an interim report of suggested interventions at classroom, school and political level. The findings and proposed measures corresponded in general with the experiences and needs of the invited 'hands-on' experts.

\section{Results}

The results will be presented in a two-fold manner. On the one hand, trends identified within the parents' stories will be reported. Furthermore, some verbatim interview 
excerpts from particular parents will be presented, either illustrating the trends or expressing particular experiences and needs of specific parents. Twenty-two excerpts from 17 different parents will be described. The excerpts have been literally translated from Dutch.

\section{Parental support for the children's educational career}

In general, the parents were committed to their children's educational career and satisfied with their support, although actual commitment varied considerably according to the different families (e.g. the organization of routine household tasks to fit the school day, help with homework, monitoring the child's school activities, providing positive feedback to the child, attending meetings with teachers and/or other parents, taking part in or assisting with school events, participating in the parents' committee).

Within the scope of this study, we were particularly interested in factors stimulating parental support and involvement on the one hand, and in obstructing factors on the other. For many parents (in particular lone parents, as well as some mothers in stepfamilies), their professional situation was a considerable obstacle to investment in their children's educational career.

It certainly makes it more difficult. Just because, for the intimacy with my child, I think it is important to help her with her homework. Not that she has to have a ten, but just that the child has the feeling of 'Mummy makes time for me'. And now she has already had to do without that for a whole week, because I have to work late. (Lone mother)

In some lone-mother families, the financial situation made it difficult to participate in school activities.

I will never participate in such an organisation and parent thing. It usually takes place in the evening and I am not going to leave him alone here every time. And I am not going to get a babysitter because that's too expensive for me. Otherwise I would do it. (Lone mother)

The meal evenings are painful. Financially, it is very difficult for me ... It is very difficult to tell the children that we cannot go. (Lone mother)

Some of the parents felt resistance towards taking part in school activities because they had faced, or feared facing, prejudices concerning their family situation among teachers and parents from traditional families.

When they went swimming, when they were in nursery school, they asked the parents to come, to help the children get dressed. That was a problem. I did it once and then never again. There you are, a man among all those women. Some of them have problems with it. You should see how they sometimes look at you and make remarks. (Lone father)

Yes, I feel that they somehow, 'Yes, that one is divorced.' Maybe that is exaggerating, it is not like it used to be anymore, but you get the label of 'divorced' and then you are less inclined to go. (Mother, stepfamily)

In order to promote the parents' involvement in their children's educational career, the following factors were mentioned as relevant: the support and involvement of the 
ex-partner or the new partner, willingness to break out of one's own isolation and the appreciation expressed by the children's teacher.

My ex-partner did not let me go to the parents' committee. And I feel good doing those things. ... It is also a feeling of self-worth. If I am going to shut myself off, that's not good for me, is it? I feel better, certainly if you are unemployed, being useful in one way or another. (Lone mother)

Some parents were motivated by feelings of guilt (they wanted to make up for the difficult situation for their children following the divorce).

So you are going to make up for it with more attention and time ... No matter how well the divorce is arranged, there is always that feeling of guilt towards the children. (Lone mother)

Parental involvement with the child's school career can diminish during the period of the crisis following the divorce, but increase again when the situation is stabilized.

I regret that I did not notice things, while for many years I was very alert to all my children's behaviour. I had a lot of work and I was simply at odds with myself, so I let it go. I have not been at school these past two months. (Lone mother)

Our findings suggest there are some differences between lone parents and parents from stepfamilies. Several lone mothers (and none of those in stepfamilies) invoked financial restrictions to participation in school activities. Furthermore, the majority of lone parents, and only a few mothers in stepfamilies, thought that it was easier for parents in (traditional) two-parent families to support their children's educational career, because there is a second parent available - parents can divide the work and support each other-and the traditional family is the dominant family model in the school. Several mothers in stepfamilies reported that the new partner may assist in supporting the child's school career: a step-parent can take care of the child while the parent attends school meetings or can help the child with homework. Other parents deliberately do not want the step-parent to be involved in the child's school career and education in general, because the step-parent is not the child's 'real' parent. For the most part, these are parents who continue to have a good relationship with the other parent of the child.

Because I do not think, when M. plays at a school party, he wants J. [step-parent] to be there. M. would like his daddy to be there. It is not because we divorced that that is not possible anymore. You have to do that for the child. (Mother, stepfamily)

We found that the four divorced lone fathers in the study were very involved with their children's school career. This could be related to the selectivity of our sample. They felt a great deal of pressure and prejudice from society with regard to their family situation and they were trying hard to prove they were 'good parents'.

I participate in everything. So, when there is something at school, for example parent contacts or information evenings, then I go. I never miss one of these things ... And family masses, we always participate ... I also drive the children when they go somewhere. (Lone father)

Some lone mothers were very involved with their child's school career as well, but 
there was more variation within the group of lone mothers. None of the fathers mentioned financial restrictions on participation in school activities. Lone mothers, unlike fathers, frequently mentioned positive feedback by the child's teacher for their involvement as being stimulating and motivating.

\section{The support offered by the school}

The majority of the parents were satisfied with the support offered by the school. However, many parents in our data-set were also displeased with the support received and had unfulfilled expectations. It is important to indicate that the parents were comprehending of the position of the school: they understood that the school cannot meet all possible children's and parents' expectations.

The experiences of the parents were closely related to the child's teacher. Some teachers were reported as investing a great deal in the psychosocial support of the children; parents experienced this kind of support in a positive way. Other teachers did not invest in the psychosocial support of the child, or only in a very limited way; their focus was on cognitive education. Parents were generally less satisfied with this kind of support.

Personal contact is very important for the child. The children perceive them as their teachers, but also as friends, friend is a big word, but they know they can count on them. And I appreciate that very much about this school. So, um, I think the children were very well supported, they made room for talking about their sorrow. (Lone mother)

I do not say he was an angel, absolutely not, but they knew what was happening at that time and I think they should have supported him somewhat more. I came to school with him several times, when he did not want to go to school, and he started to fight against that violently. And some teachers said: 'Come on, N, now you show what kind of a person you are.' Instead of supporting that child and saying: 'Come with me.' That was what he needed at that moment and he did not get it. (Lone mother)

The importance of the teacher with regard to the satisfaction or dissatisfaction of parents was related in most schools to the lack of a policy regarding the relationship between parents and the school. This revealed itself, for example and in particular, in the registration of personal information about the children and their family and in the internal and external communication at school concerning the children's family situation. Many parents had to fill in a form giving personal and family information when the child first registered at school. Some of the schools asked parents to update this form at the beginning of every school year. The content of these forms varied depending on the schools: sometimes it was very limited (address and profession of the parents); sometimes it was very detailed. Consequently, notification to the school of (changes in) the family situation was in most cases left to the initiative of the parents. According to most parents, it is in the best interests of the child that the school be informed about the family situation.

I think they should know, I think they even have to know. If there are problems with the children, after all they spend more time at school than at home. I think that the teacher 
has to be a confidant in one way or another. But if they do not know anything about the family situation, if people do not know, they cannot help. (Mother, stepfamily)

Many parents expect the school to show initiative in talking with the parents and giving information about the child's progress and well-being; in particular, if this relates to the specific family situation.

Well, that they show some enterprise themselves. If I had not sent that letter to the school, I mean, would I have heard anything from them? Maybe some people are less emancipated or they do not dare or they feel very bad and they are not able to contact the school at that moment. I think the school has to show more initiative. (Mother, stepfamily)

Certain parents referred explicitly to a partnership between school and parents as a reason for informing the school about the family situation.

I did not have a big problem with being alone, but with parenting alone, I did. But I was not alone; the school also educates the child. And for me it was important to communicate, for example, how do I have to apply things from school in the home? (Lone mother)

I think that it has to be a whole. After all, the children live in two worlds, at home and at school. I do not think they have to be separate. (Lone mother)

The parents expected schools to handle personal information with great care and discretion and that they would pass it on (only) to the proper people. In other words, they expected schools to have a discreet and efficient internal communication policy. In reality, such a policy did not exist in most of the schools involved in the study.

And they give no names and even that means a lot to me. And in the other school, it was 'that one is alone, and that one does not have a husband and that one has this and that'. There, you really are stigmatised. (Lone mother)

Four parents did not want the school to ask for information about the family. They regarded this information as private and thought that the school did not have to become involved in family matters.

That is not something we talk about. I prefer it like that, because they do not have to interfere with it. Because I think if a child cannot cope with it, you will notice that his results are not good or that he is nervous or see how they behave on the playground. That they intervene at that moment or ask for information, but if everything is OK they do not need to know more about it. (Mother, stepfamily)

Two lone parents who thought it was important to inform the school about the family situation reported negative feelings about the school asking for that information because of (fear of) prejudice among the teachers. They were afraid that their children would be treated differently and that this might have negative consequences for them.

Yes, they ask for it and I find it terrible. Certainly, at the time of the divorce it was very painful for me. You have to repeat it so many times. You also feel, I think people always have prejudices if they have not experienced it themselves ... Actually, I would like my children to be treated as if they came from an ordinary family background, and me too. (Lone mother) 
One-third of the parents experienced negative reactions in the school with respect to the changes in their family situation. All these parents were disappointed about these reactions. Again, the parents indicated that these reactions varied considerably according to the individual teachers. On the other hand, some parents observed a positive change in the school's attitude; in particular, the teacher's attitude.

I said: 'I know he is a difficult child.' But then she said: 'It is because of your situation.' And it really came across like that and then I thought, I have to look for another school, because I have no confidence anymore. There was so much disapproval ... Before they talked easily with me, but all of a sudden they did not talk anymore. An awkward silence fell and I didn't like that. So I was very disappointed with that school at that time. (Lone mother)

In my opinion, that school, they pass judgment on something they know nothing about. They think that because I am a divorced man, if you are divorced, you are bad, I am to blame for the divorce. Although they do not know what the divorce is about. I had that feeling, that they ignored me. (Lone father)

We complete this description by giving an overview of support practices that were significant to parents, practices that certain parents already had and from which others would like to benefit. Parents expected the school to be open-minded and respectful of their family situation. Straightforward and concerned teachers, capable of supporting the children particularly during periods of crisis, are of an inestimable value to children as well as to their parents. The parents explicitly did not ask for and did not want preferential treatment for their children. They only asked for some careful attention for the specific situation that determines their children's everyday life, especially during crises.

Certain parents appreciated the fact that the school created facilities for parents to contact each other and exchange experiences. When there were more serious problems, many parents did not know to whom they could turn for advice or help. Some parents were rather hesitant to appeal for more specialist help. They expected the school and the school psychology services to inform them about and introduce them to specialist centres or professionals.

The parents asked that practical and administrative matters, relating to their specific situation, be handled in a flexible way. For example, the child should be allowed to keep his/her school report until the other parent has seen it. As another example, the child should be allowed to make two handicrafts for Mother's Day, if he/ she wants to give a present to the father's new partner too.

In the curriculum, as well as in the textbooks, the traditional family is still the frame of reference. Parents indicated that it is important for the diversity of family situations to be represented in didactical methods and material, so that all children can identify with them and speak frankly about their family life.

Nowadays, divorce is a hot topic. But at school they do not talk about it at all. Children feel like, or I have the impression that they are outsiders, not normal, because their mum and dad are not living together. It remains a taboo, it is hushed up. (Lone mother) 


\section{Discussion}

Our findings are based on small-scale qualitative research with 40 self-selected families. The purpose of this study was to give an overview of the variation in the possible experiences and needs of divorced parents, with respect to supporting their children's educational career in primary school. This required an in-depth study of a limited number of subjects. Another consequence of putting the criteria of variation in the foreground was that our data-set was not a representative sample of the whole population of divorced lone-parent families and stepfamilies in Flanders. Referring to this goal and method, it is not surprising that the results show a wide variety of experiences and perceptions, as well as different needs for support among different families.

Although actual involvement varied, all divorced parents in our study were committed to their child's school career. More generally, it has been revealed that meeting children's needs remains a moral imperative for divorced parents (and stepparents) (for example, Ribbens McCarthy et al., 2003; Smart \& Neale, 1999). Stimulating and obstructing factors for 'parental support' refer to the financial and professional situation, the (lack of) availability of another parent, the quality of the relationship between the parents (amount of conflict) and the quality of relationships with other parents and teachers. A particularly striking finding from our study is that a considerable number of mothers and fathers experienced prejudice from teachers or other parents towards divorced parents. Similar results were found by Standing (1999) through interviews with lone mothers. These findings might be explained to a large extent by the public image of divorce; in another study we found that many lone parents reported negative reactions from others in a broader social context than the school (Vandemeulebroecke et al., 2003). Furthermore, we can refer to the argument by Griffith and Smith (1991), mentioned in the Introduction, which seems mainly to apply to single mothers: schools construe lone mothers as (supposedly) inadequate because they face so many obstacles (e.g. financial restrictions, working long hours) that they cannot adopt the middle-class model of parental involvement. According to Standing (1999), one way of resolving the contradictions of the demands of parental involvement and working (lone) motherhood is to encourage fathers to become involved in schooling in particular, and parenting in general. One 'positive' aspect of divorce might be that custodial fathers or fathers in a shared custody arrangement become more involved with their child's school education. Yet the fathers in our study felt they were perceived as incompetent parents in general and stigmatized as 'bad men', to blame for the divorce. A change in mentality is needed if the school wants to encourage fathers to become involved. However, we must be very careful with gender comparisons, since only four men participated in our study; these ideas are mainly to be seen as interesting hypotheses for further research.

Prejudices and negative reactions can, at least for some parents, have a negative influence on their involvement in school activities (cf. Vincent, 1996). A positive, accepting and respectful attitude from the school towards a diversity of family situations is crucial to encouraging parents to become involved in the school careers of 
their children: 'The one factor above all others which would benefit lone mothers in their involvement in their children's schooling, is the end to the demonisation of lone motherhood, and a shift to a celebration of different, but equal, family structures' (Standing, 1999, p. 493). Moreover, schools should take account of the financial and professional situation of the family. For example, schools can provide some kind of payment programme for parents in a difficult financial situation. They can also create possibilities for working (lone) parents to participate in parents' evenings by bearing in mind the schedules of these parents when organizing such evenings. Another essential aspect is discreet and efficient communication between (both) parents and the school, as well as within the school itself. Pong (1997) emphasizes the importance of social networks of parents at school for lone-parent and stepfamilies. These networks give parents the opportunity to exchange information and experiences about school policy and practices and to provide lone parents and step-parents with ideas about parenting practices and strategies that can enhance their own parenting.

Concerning the support offered by the school, parents emphasized that they did not want any kind of preferential treatment for themselves or their children. They merely asked for an attitude of openness to diverse family forms and lifestyles, some careful attention and understanding of the events in child's daily life and a flexible way of handling family-related administrative and practical matters at school.

The personality of the teacher plays a crucial role, according to the parents' experiences. A positive relationship between the teacher and their children is very important, not only with regard to the well-being of the children at school, but also with regard to their behaviour and school performances. When parents are less competent during the crisis period in family transitions, the school can fulfil a complementary parenting role. Other recent studies have shown that parents in general turn very often to teachers when they have questions concerning parenting and/or their children; teachers are perceived as partners in education (Klaassen \& Leeferink, 1998).

In today's society, schools are challenged by the diversity of family situations in which children live and should find a way of handling this reality in one way or another. Based on the findings of our study, we have come to the following general suggestion: schools should make a priority of establishing a policy regarding the family-school relationship, based on the principle of partnership between parents and teachers. In this way, the support offered by both the family and the school environment can be enhanced with regard to optimum development and the school career of children. As Epstein (1990, p. 123) states, 'all families must understand the schools their children attend. All schools must understand the families that they serve. And, all schools and families must understand how they can influence each other to benefit the children that they share'. Partnership can be aimed not only at educational effectiveness; the emphasis should be on creating equal opportunities for all children (cf. David, 1993). It implies an attitude of shared responsibility and a willingness to collaborate in a context of equality and clarity of role, as well as mutual support. Positive interaction and communication between parents and school is an absolute condition within a policy regarding the family-school relationship. This involves 
respect for diversity in children's and families' backgrounds, whether they refer to differences in gender, ethnic origin, social class or family form. Our findings suggest that optimum support for each child has to be achieved in collaboration between parents and the school, taking into account the needs and possibilities of the child and the parents. As a consequence, schools will have to individualize their support and make special efforts for children and parents in particular and/or difficult situations. Empowerment and network-building between parents, schools and educational, mentoring and counselling institutions are also of great importance (cf. de Acosta, 1996).

In order to implement a family-school policy, the parents from our study mentioned that teacher education was an issue of vital importance. Research has shown that many teachers do not possess the knowledge, attitudes and skills needed to collaborate effectively with families from diverse backgrounds (de Acosta, 1996; Morris \& Taylor, 1998). Teacher training courses or teacher preparation programmes on the subject of family involvement in school education are needed. A limited number of studies showed the positive effects of teacher training on the students' perceptions of their comfort and competence levels in planning and implementing family involvement programmes and in working with families in general (Morris \& Taylor, 1998; Katz \& Bauch, 1999).

\section{Acknowledgement}

This study was funded by the Flemish Ministry of Education (OBPWO 99.07).

\section{Note}

1. The parents in our study group are those with whom the children are living most of the time. The term 'custodial' is used in this respect.

\section{References}

Bosman, R. \& Louwes, W. (1989) Gezinssituaties en onderwijskansen. Een toetsing van verklaringen voor de schoolloopbaanverschillen tussen kinderen uit eenoudergezinnen en tweeoudergezinnen (Nijmegen, Catholic University).

Child and Family (2001) The child in Flanders (Brussels, Kind en Gezin). Available online at: http:// www.kindengezin.be/English_pages/default.asp (accessed 7 July 2003).

David, M. (1993) Parents, gender and education reform (Cambridge, Polity Press).

de Acosta, M. (1996) A foundational approach to preparing teachers for family and community involvement in children's education, Fournal of Teacher Education, 47, 9-15.

Denzin, N. K. \& Lincoln, Y. S. (Eds) (1998) Strategies of qualitative inquiry (Thousand Oaks, CA, Sage).

Ditch, J., Barnes, H. \& Bredshaw, J. (1998) Developments in national family policies in 1996. European Observatory on National Family Policies/DGV (University of York, Social Policy Research Unit).

Downey, D. B. (1994) The school performance of children from lone mother and lone father families: economic or interpersonal deprivation, fournal of Family Issues, 15, 129-147. 
Duncan, S. \& Edwards, R. (Eds) (1997) Lone mothers in an international context: mothers or workers? (London, OCL).

Duncan, S. \& Edwards, R. (1999) Lone mothers, paid work and gendered moral rationalities (London, MacMillan).

Entwisle, D. R. \& Alexander, K. L. (1996) Family type and children's growth in reading and maths over the primary grades, fournal of Marriage and the Family, 58, 341-355.

Epstein, J. L. (1990) School and family connections: theory, research and implications for integrating sociologies of education and family, in: D. Ungerer \& S. Sussman (Eds) Families in community settings: interdisciplinary perspectives (New York, The Haworth Press).

Eurostat (1998) Statistiques en bref (Luxemberg, Eurostat).

Felner, R. D., Brand, S., Dubois, D. L., Adan, A. M., Mulhall, P. F. \& Evans, E. G. (1995) Socioeconomic disadvantage, proximal environmental experiences, and socioemotional and academic adjustment in early adolescence: investigation of a mediated effects model, Child Development, 66, 774-792.

Geenen, G. (1999) Een introductie tot QSR NUD*IST 4 (K.U. Leuven, Faculty of Psychology and Pedagogical Sciences).

Golombok, S. (2000) Parenting: what really counts? (London-Philadelphia, Routhledge).

Griffith, A. I. \& Smith, D. E. (1991) Constructing cultural knowledge: mothering as discours, in: J. G. Askell \& A. McLaren (Eds) Women and education (Calgary, Detselig).

Guba, E. G. (1981) Criteria for assessing the trustworthiness of naturalistic inquiries, Educational Communication and Technology fournal, 29, 75-91.

Haskey, J. (1994) Stepfamilies and stepchildren in Great Britain (London, OPCS).

Haskey, J. (1998) Families: their historical context and recent trends in the factors influencing their formation and dissolution, in: M. E. David (Ed.) The fragmenting family: does it matter? (London, IEA).

Hetherington, E. M. (1993) An overview of the Virginia Longitudinal Study of divorce and remarriage with a focus on early adolescence, Fournal of Family Pyschology, 7, 39-56.

Hetherington, E. M., Bridges, M. \& Insabella, G. M. (1998) What matters? What does not? Five perspectives on the association between marital transitions and children's adjustment, American Psychologist, 53, 167-184.

Katz, L. \& Bauch, J. (1999) The Peabody family initiative: preservice preparation for family/school collaboration, School Community fournal, 9, 49-69.

Klaassen, C. \& Leeferink, H. (1998) Partners in opvoeding in het basisonderwijs. Ouders en docenten over de pedagogische opdracht en de afstemming tussen gezin en school (Assen, Van Gorcum).

Lareau, A. (1989) Home advantage: social class and parental intervention in elementary education (London-New York, The Falmer Press).

Miles, M. B. \& Huberman, A. M. (1994) Qualitative data analysis: an expanded sourcebook (Thousand Oaks, CA, Sage).

Morgan, P. (1998) An endangered species? in: M. E. David (Ed.) The fragmenting family: does it matter? (London, IEA).

Morris, V. \& Taylor, S. I. (1998) Alleviating harriers to family involvement in education: the role of teacher education, Teaching and Teacher Education, 14, 219-231.

Pong, S. (1997) Family structure, school context and eight-grade math and reading achievement, fournal of Marriage and the Family, 59, 734-746.

Ribbens McCarthy, J., Edwards, R. \& Gillies, V. (2003) Making families: moral tales of parenting and step-parenting (York, Sociology Press).

Smart, C. \& Neale, B. (1999) Family fragments? (London, Polity Press)

Speltinckx, E. \& Jacobs, T. (1996) Kleuters en hun huishoudens in de kijker (Antwerp, University of Antwerp).

Standing, K. (1999) Lone mothers and 'parental' involvement: a contradiction in policy? fournal of Social Policy, 28, 479-495. 
Vandemeulebroecke, L., De Munter, A., Colpin, H. \& Kuti, K. (2003) Kennisverwerving en ontwikkeling van beleidsscenario's voor een optimalisering van de (pedagogische) hulpverlening aan eenoudergezinnen (K.U. Leuven, Department Pedagogical Sciences).

Vincent, C. (1996) Parents and teachers: power and participation (London, Falmer Press). 
